\title{
The use of a square mesh codend and sorting grids to reduce catches of young fish and improve sustainability in a multispecies bottom trawl fishery in the Mediterranean
}

\author{
FRANCISCO SARDÀ, NIXON BAHAMON, BALBINA MOLÍ \\ and FRANCESC SARDÀ-PALOMERA \\ Institut de Ciències del Mar (CMIMA-CSIC), Passeig Marítim de la Barceloneta 37-49, 08003 Barcelona, Spain. \\ E-mail: siscu@icm.csic.es
}

SUMMARY: In order to improve the capacity of bottom trawl fishing gears to reduce catches of young fish and discards in a highly exploited demersal trawl fisheries in the Mediterranean, the size-selection performance of a 36-mm square-mesh codend and two sorting grids with 20 and $15 \mathrm{~mm}$ bar spacing was assessed. Alternate hauls were used to assess the selectivity of 36$\mathrm{mm}$ square-mesh codend. Selectivity of sorting grids was assessed using a double codend in which fish that escaped through the grid were captured in the lower codend while other fish were guided into the upper codend. The mean selection length $\left(L_{50}\right)$ for European hake was $18.5 \mathrm{~cm}$ and that for the Atlantic horse mackerel was $14.0 \mathrm{~cm}$ with the $36-\mathrm{mm}$ square-mesh codend These values are close to their current minimum landing sizes $(20 \mathrm{~cm}$ for hake and $12 \mathrm{~cm}$ for horse mackerel). The sorting grid with $20-\mathrm{mm}$ bar spacing showed $L_{50}$ value of $13.3 \mathrm{~cm}$ for hake, suggesting that a larger grid-spacing would be needed to obtain sufficient sorting performance. Similarly, for Atlantic mackerel the estimated $L_{50}$ of $14.3 \mathrm{~cm}$ indicates that larger grid spacing is required to attain an $L_{50}$ that would be close to the current MLS $(18 \mathrm{~cm})$. For Atlantic horse mackerel and red mullet, the $L_{55}$ obtained with the sorting grid with 20-mm bar spacing was close to the MLS of these species (the MLS of red mullet is $11 \mathrm{~cm}$ ). The selectivity of the sorting grid with $15-\mathrm{mm}$ bar spacing was generally very poor. Size-selection performance of sorting grids was assessed for the first time in the local fisheries. In order to effectively improve size-selection, seasonal and depth-dependent differences between target and by-catch species must be taken into account, which is a good indicator of the difficulty of implementing a single mesh size or grid spacing in the Mediterranean demersal trawl fishery.

Keywords: Mediterranean Sea, sorting grid, square mesh, selectivity, multispecies fishery, bottom trawl, European hake, Atlantic horse mackerel, Atlantic mackerel, red mullet.

RESUMEN: EL USO DE COPO DE MALLA CUADRADA Y REJLLAS SEPARADORAS PARA REDUCIR LAS CAPTURAS DE PECES JUVENILES Y MEJORAR LA SOSTENIBILIDAD DE UNA PESQUERÍA MULTIESPECÍFICA DE ARRASTRE DE FONDO EN EL MEDITERRÁNEO. - Con el propósito de mejorar la capacidad de las redes de arrastre de fondo para reducir las capturas de peces juveniles y descartes en una pesquería multiespecífica altamente explotada en el Mar Mediterráneo, se evaluó la selectividad de las tallas de diversas especies demersales mediante el uso de una malla cuadrada de $36 \mathrm{~mm}$ y dos rejillas con separación entre barras de 20 y $15 \mathrm{~mm}$. Se usó el método de lances alternativos para evaluar la selectividad del copo de malla cuadrada. La selectividad de las rejillas se evaluó mediante un doble copo. Los peces que escaparon de la rejilla se capturaron en el copo inferior y el resto del pescado se guió y capturó en el copo superior. Con el copo de malla cuadrada, la talla media de madurez $\left(L_{50}\right)$ de la merluza y el jurel fue respectivamente de $18,5 \mathrm{~cm}$ y $14,0 \mathrm{~cm}$. Estos valores se aproximan a la talla mínima de selección (MLS para la merluza es de $20 \mathrm{~cm}$ y para la jurel es de $12 \mathrm{~cm}$ ). Con la rejilla con separación entre barras de $20 \mathrm{~mm}$, la $L_{50}$ de la merluza fue de $13,3 \mathrm{~cm}$, lo cual sugiere que sería conveniente aumentar la separación entre barras para obtener una $L_{50}$ más próxima a la MLS. La caballa se seleccionó con una $L_{50}$ de 14,3 , por debajo de la MLS de $18 \mathrm{~cm}$. El jurel y el salmonete mostraron $L_{50}$ cercana la MLS (MLS del salmonete es $11 \mathrm{~cm}$ ). La rejilla con espacios de $15 \mathrm{~mm}$ fue muy poco selectiva. Este es el primer trabajo que se realiza en el área en el que se compara el funcionamiento de la malla cuadrada y las rejillas separadoras. La tecnología de las rejillas separadoras se aplicó por primera vez con el objetivo de mejorar la explotación de las pesquerías locales. La mejora en la selección de tallas requiere tener en cuenta la variación estacional y en profundidad de las especies objetivo y especies acompañantes, lo que demuestra la dificultad de implementar una sola malla o rejilla en toda la pesquería demersal de arrastre del Mediterráneo.

Palabras clave: Mar Mediterráneo, rejilla separadora, malla cuadrada, selectividad, pesquería multiespecífica, arrastre de fondo, merluza, jurel, caballa, salmonete. 


\section{INTRODUCTION}

Fishing pressure generated by the multispecies trawl fishery in the Mediterranean Sea has increased during the last two decades and many commercial species are now overexploited. An indication of this is the high share of juvenile fish in the catches (Larrañeta et al., 1969; Stergiou et al., 1997; Lleonart, 2001; Sánchez et al., 2004). Poor selectivity of bottom trawls using the legislated $40-\mathrm{mm}$ diamond mesh codend greatly contributes to the unfavourable catch composition and relatively high discard rates (Martín et al., 2001; Sánchez et al., 2004). Total discards in the western Mediterranean bottom trawl fishery range from 17 to $34 \%$ of the total catch weight (Sánchez et al., 2004). It is worth noting that in Mediterranean fishery, a fraction of undersized fish are not discarded but marketed.

More than 300 benthic and epibenthic species have been reported in the catches of the commercial trawler fleet targeting European hake (Merluccius merluccius) in the western Mediterranean (Martín et al., 2001). The percentage of hake below the minimum landing size (current MLS is $20 \mathrm{~cm}$ ) caught and discarded is highly variable: it depends, among other factors, on the fishing ground and season, and may be up to $64 \%$ (in numbers) of the total hake catch (Martín et al., 2001; Sánchez et al., 2004). Furthermore, many other commercially important species caught in large quantities are undersized and immature, mainly due to the use of a $40 \mathrm{~mm}$ diamond-shaped mesh that is poorly selective, preventing the small individuals from escaping the nets (e.g. Sardá et al., 2004).

It has been well demonstrated that by-catch and discards can be reduced in trawl fishery, for instance, by using a square mesh codend or a sorting grid (Madsen and Hansen, 2001; Polet, 2002; Valdemarsen and Suuronen, 2003). Few studies, however, have assessed the performance of these techniques in the highly multispecies trawl fishery of the Mediterranean Sea (Steward, 2002). Early selectivity experiments carried out off the Ebro River delta (NW Mediterranean) examined the selectivity of various diamond-mesh codends (Larrañeta et al., 1969). Recently, the selectivity of a $40-\mathrm{mm}$ square mesh codend was tested in the deepwater $(>500 \mathrm{~m})$ crustacean trawl fishery off the Balearic Islands in the western Mediterranean (Guijarro and Massutí, 2006). Preliminary and experimental selectivity trials using a sorting grid (with 20-mm bar spacing) to reduce undersize hake in trawl catches produced promising results, allowing roughly $50 \%$ of undersized hake to escape (Sardà et al., 2005; Sardà et al., 2004).

To reduce catches of young fish and improve sustainability of bottom trawl fisheries in the Iberian Mediterranean, trials with a square-mesh codend and a codend equipped with sorting grid were conducted. These trials were expected to increase our knowledge on the selectivity performance of these new sorting techniques in the Mediterranean multispecies conditions, and to provide solutions that are acceptable for the fishing industry. Selectivity parameters are used to assess and compare the performance and impacts of these techniques.

\section{METHODS}

\section{Field experiments}

The experiments were performed on board the commercial trawler "Germans Fèlix" (18.3 m, 440 HP) at a mean depth of $73 \mathrm{~m}$ (between 45 and 93 $\mathrm{m}$ ) in June and $38 \mathrm{~m}$ (between 20 and $55 \mathrm{~m}$ ) in September 2003 (Fig. 1) off the Ebro River delta (St. Carles de la Ràpita, Spanish coast, NW Mediterranean). In the June trials, a 36-mm stretch square-mesh codend (SM36) and two sorting grids with a bar spacing of $15 \mathrm{~mm}$ (BS15) and $20 \mathrm{~mm}$

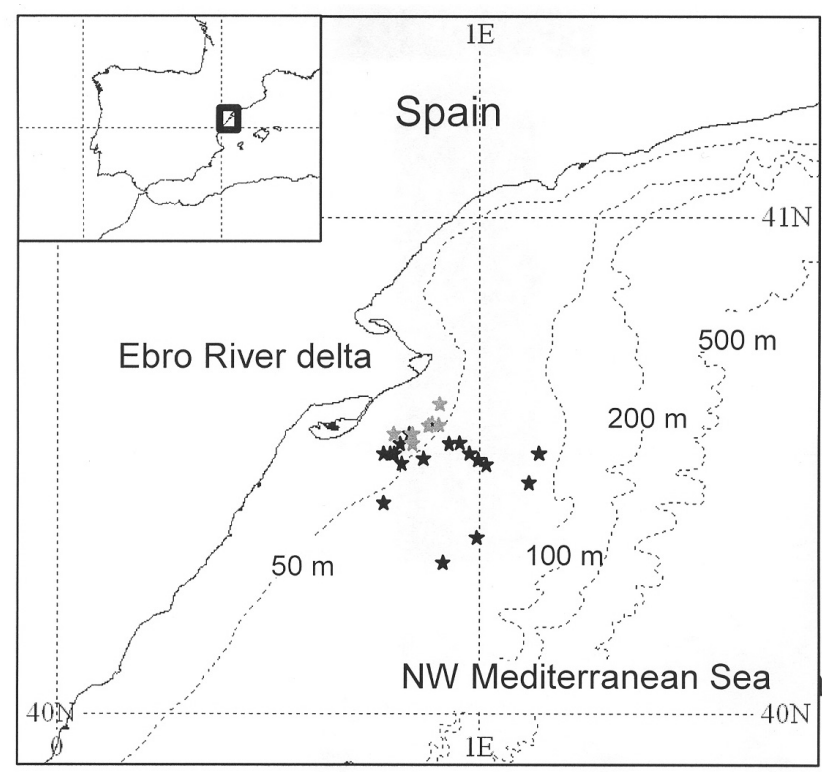

FIG. 1. - The study area showing the start-points of the experimental trawl tows. Black stars are tows carried out in June 2003 and grey stars are tows carried out in September 2003. 


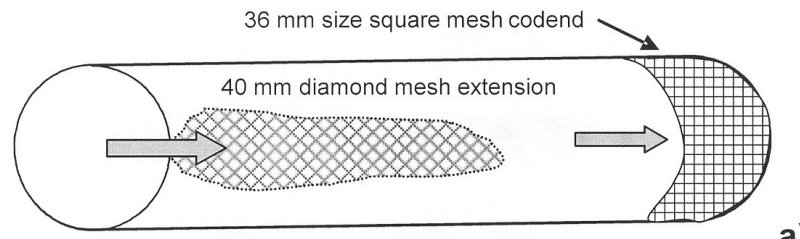

a)

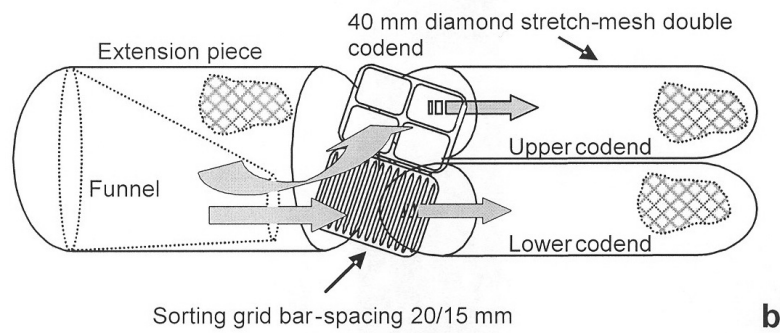

b)

FIG. 2. - Schematic drawings of (a) the square mesh codend and (b) the sorting grids (frame $100 \times 145 \mathrm{~cm}$ ) tested in this study. The lower section of the grid allowed small individuals to escape through the bars to a lower codend, while the grid guided larger fish into the upper codend (representing the catch).

(BS20) were tested. In the September trials, only the 20-mm sorting grid was tested (BS15 was not included because of the poor selectivity observed in June).

The 36-mm square mesh codend was made of non-knotted braided polyethylene (PE) netting (twine diameter $3 \mathrm{~mm}$ ) and was ca $3 \mathrm{~m}$ long (Fig. 2a). It was attached to the codend extension made of $40 \mathrm{~mm}$ diamond mesh (in circumference, the square mesh codend had half the meshes of the extension). The sorting grids (BS20 and BS15) were made of rigid plastic, and consisted of two hinged sections, one open and one with a grid. These sections were hinged together and fitted at the end of a standard 40-mm diamond mesh extension piece (Fig. 2b). The only technical difference between the two sorting grids was the spacing between the bars. Selective performance of sorting grids was assessed using a double codend method by which grid-escapees were captured in the lower codend and those fish that were not sorted through the grid were guided by it into the upper codend (representing the catch) (Fig.
$2 \mathrm{~b})$. The collection codends were made of $40-\mathrm{mm}$ diamond stretch mesh PE netting (twine, diameter $5 \mathrm{~mm}$ ). The guiding funnel in front of the grid guided the fish towards the lower part of the grid (Fig. 2b).

An alternate haul method was used to assess the selectivity of the SM36 codend. This method was chosen instead of the codend-cover method, in order to prevent possible disturbances of the cover on the filtering of the two codends. The control was a standard 40-mm stretch knotted diamond-mesh codend (DM40; PE twine diameter $5 \mathrm{~mm}$ ), which shows negligible selection in the fish length range of interest.

In total, 18 tows were carried out in June and 7 in September (Table 1). Six hauls were conducted in the alternate haul trials, three with both codends (SM36 and DM40). Mean tow duration was $60 \mathrm{~min}$ and mean towing speed 3.7 knots. Rigging and overall performance of the experimental trawl (e.g. door spread, mouth opening) during towing was monitored using Scanmar acoustic sensors.

Catch sampling was focussed on the fishing grounds in which most abundant commercial species occur: European hake, Atlantic horse mackerel (Trachurus trachurus), poor cod (Trisopterus minutus capelanus), red mullet (Mullus barbatus), Atlantic mackerel (Scomber scombrus), spotted flounder (Citharus linguatula), and gurnards (Triglidae). Individual species were measured to the nearest $0.1 \mathrm{~cm}$ total length (TL), and total catch per species was weighted $( \pm 1 \mathrm{~kg})$.

\section{Data analyses}

The SELECT (Share Each LEngth's Catch Total) model (Millar, 1992) was used to fit data to logistic and Richard's functions. For the square mesh experiment, the probability that a fish of length $l$ entering the gear will be retained by the net was assumed to be $\mathrm{r}(l)=p \exp (a+b l) /[1-p$ $+\exp (a+b l)]$. The values of the parameters $p, a$,

TABLE 1. - Date, number of hauls and mean trawling depth.

\begin{tabular}{lcc}
\hline Sorting device/codend & Date & Number of hauls \\
\hline Sorting grid with 15-mm bar spacing (BS15) & 11-12 Jun 2003 & 6 \\
Sorting grid with 20-mm bar spacing (BS20) & 17-18 Jun 2003 depth (m) & 6 \\
Sorting grid with 20-mm bar spacing (BS20) & 18-19 Sep 2002 & 7 \\
40-mm diamond mesh codend (DM40) & 10-Jun-03 & 3 \\
36-mm square-mesh codend (SM36) & 20-Jun-03 & 37 \\
\hline
\end{tabular}


$350 \bullet$ F. SARDÀ et al.

TABLE 2. - Best fitting selectivity models and parameter ( $a, b, p$ and $\delta$ ) values with standard errors (SE) indicated.

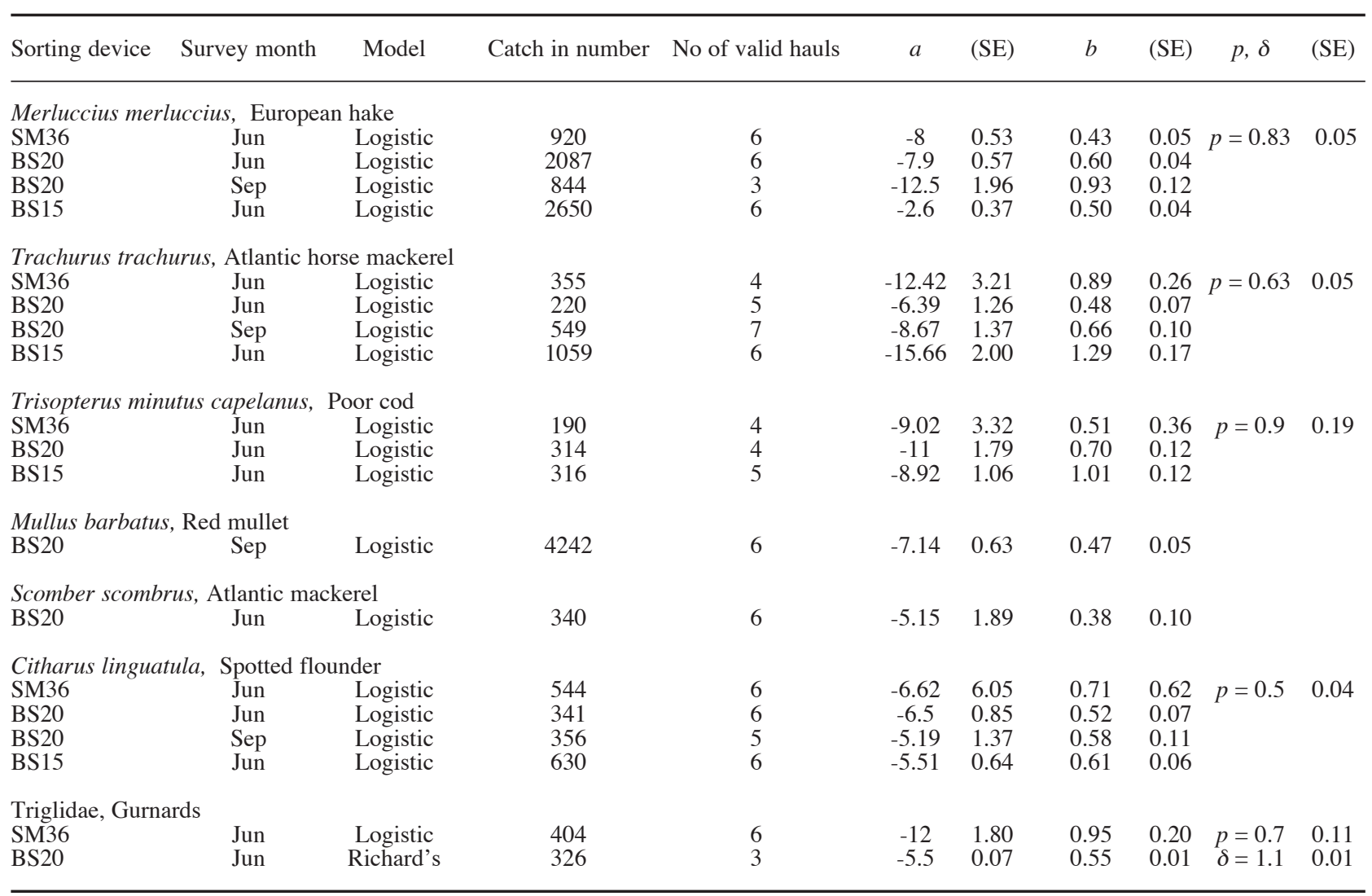

and $b$ were estimated by maximizing the log-likelihood function (Tokai, 1997). The parameter $p$ represents here the fishing intensity (Millar and Fryer, 1999). Parameters $a$ and $b$ were used to calculate the $50 \%$ selection length, $L_{50}=-a / b$, and the selection range, $S R=2 \ln (3) / b$. The best model fits (Table 2) were found by testing the hypotheses $H_{0}: p=0.5$ (equal split) and $H_{1}: p \neq 0.5$ (estimated split) using Pearson's chi-square statistic. For the sorting grid experiment, the equation used to calculate the best parameter values for the experimental sorting grids was based on $r(l)=$ $\exp (a+b l) /[1+\exp (a+b l)]^{1 / \delta}$. The value of $\delta$ is a measure of the asymmetry of the selection curve around $L_{50}$. The best fitting models (Table 2) were found by testing the hypotheses $H_{0}: \delta=1$ for the logistic curve, and $H_{1}: \delta \neq 1$ for the Richard's curve using Pearson's chi-square statistic. Deviance residuals and parameter errors indicated significant inter-haul variability, so an appropriate adjustment was made to correct the over-dispersion in the standard errors for the selection parameters and residual deviances (Wileman et al., 1996).

\section{RESULTS}

Merluccius merluccius: The 36-mm square mesh codend produced for hake an $L_{50}$ of $18.5 \mathrm{~cm}$ and selection range $(S R)$ of $5.1 \mathrm{~cm}$ (Table 3 ). The $20-\mathrm{mm}$ sorting grid, on the other hand, produced for $M$. merluccius an $L_{50}$ of only $13.1 \mathrm{~cm}$ in June and 13.5 $\mathrm{cm}$ in September. The selection range of $20-\mathrm{mm}$ grid was $3.1 \mathrm{~cm}$ in June and $2.36 \mathrm{~cm}$ in September, i.e., substantially smaller than that of the square mesh codend, suggesting a sharper selectivity performance of a grid (smaller $S R / L_{50}$ ratio). The $15-\mathrm{mm}$ sorting grid (BS15) showed poor selectivity for $M$. merluccius ( $L_{50}$ of $5.9 \mathrm{~cm}, S R$ of $3.5 \mathrm{~cm}$ ).

Trachurus trachurus: The 36-mm square mesh codend showed a slightly higher $L_{50}(14.0 \mathrm{~cm})$ for horse mackerel than the 20-mm sorting grid (13.2 cm) (Table 3). The $15-\mathrm{mm}$ grid had an $L_{50}$ of 12.0 $\mathrm{cm}$, which is exactly the current minimum landing size of this species. The selection range $(S R)$ obtained with the 36-mm square mesh codend was substantially narrower than that obtained with the 20-mm sorting grid (Table 3 ). 
TABLE 3. - Estimated selection parameters $\left(L_{50}=\right.$ mean selection length, $S R=$ selection range) and their standard errors (SE) for most important species. The minimum landing size (MLS) for the species is shown for comparison with the $L_{50}$.

\begin{tabular}{|c|c|c|c|c|c|c|c|}
\hline Sorting device & Month & MLS (cm) & $L_{50}(\mathrm{~cm})$ & (SE) & $S R(\mathrm{~cm})$ & (SE) & $S R / L_{50}$ \\
\hline \multicolumn{8}{|c|}{ Merluccius merluccius, European hake } \\
\hline SM36 & Jun & 20 & 18.47 & 1.42 & 5.07 & 0.59 & 0.27 \\
\hline BS20 & Jun & & 13.14 & 0.42 & 3.13 & 0.44 & 0.24 \\
\hline BS20 & Sep & & 13.45 & 0.24 & 2.36 & 0.29 & 0.12 \\
\hline BS15 & Jun & & 5.88 & 0.34 & 3.48 & 0.35 & 0.59 \\
\hline \multicolumn{8}{|c|}{ Trachurus trachurus, Atlantic horse mackerel } \\
\hline SM36 & Jun & 12 & 14.03 & 0.87 & 2.48 & 0.74 & 0.18 \\
\hline BS20 & Jun & & 13.22 & 0.36 & 4.55 & 0.50 & 0.34 \\
\hline BS20 & Sep & & 13.13 & 0.74 & 3.33 & 0.70 & 0.25 \\
\hline BS15 & Jun & & 12.05 & 0.25 & 4.24 & 0.23 & 0.35 \\
\hline \multicolumn{8}{|c|}{ Trisopterus minutus capelanus, Poor cod } \\
\hline SM36 & Jun & 11 & 17.53 & 7.02 & 4.27 & 2.96 & 0.24 \\
\hline BS20 & Jun & & 15.71 & 0.32 & 3.14 & 0.55 & 0.20 \\
\hline BS15 & Jun & & 8.82 & 0.42 & 2.17 & 0.26 & 0.25 \\
\hline \multicolumn{8}{|c|}{ Mullus barbatus, Red mullet } \\
\hline $\mathrm{BS} 20$ & Sep & 11 & 10.4 & 0.45 & 3.9 & 0.53 & 0.38 \\
\hline \multicolumn{8}{|c|}{ Scomber scombrus, Atlantic mackerel } \\
\hline BS20 & Jun & 18 & 14.25 & 1.59 & 4.25 & 1.48 & 0.30 \\
\hline \multicolumn{8}{|c|}{ Citharus linguatula, Spotted flounder } \\
\hline SM36 & Jun & $\mathrm{nr}$ & 9.27 & 1.17 & 3.08 & 2.65 & 0.33 \\
\hline BS20 & Jun & & 10.62 & 0.24 & 6.08 & 0.54 & 0.57 \\
\hline BS20 & Sep & & 8.97 & 0.7 & 3.80 & 0.74 & 0.42 \\
\hline BS15 & Jun & & 9.82 & 0.3 & 3.06 & 0.33 & 0.31 \\
\hline \multicolumn{8}{|c|}{ Triglidae, Gurnards } \\
\hline SM36 & Jun & $\mathrm{nr}$ & 12.63 & 1.08 & 2.31 & 0.49 & 0.18 \\
\hline BS20 & Jun & & 9.76 & 0.18 & 4.12 & 0.05 & 0.42 \\
\hline
\end{tabular}

Trisopterus minutus capelanus: For poor cod, the $36-\mathrm{mm}$ square mesh codend and the $20-\mathrm{mm}$ grid showed $L_{50}$ values of $17.5 \mathrm{~cm}$ and $15.7 \mathrm{~cm}$ respectively (Table 3 ). These values are 5-7 $\mathrm{cm}$ above the current MLS of this species $(11 \mathrm{~cm})$; that is, fishermen would lose a greater part of the catch of this species. The $15-\mathrm{mm}$ grid achieved an $L 50$ of $8.8 \mathrm{~cm}$. The estimated selection ranges of the $36-\mathrm{mm}$ square mesh codend $(4.3 \mathrm{~cm})$ and the $20-\mathrm{mm}$ sorting grid (3.14) are relatively similar, suggesting that for $T$. minutus capelanus the same selectivity performance (sharpens) can be achieved with both types of selection technique.

Mullus barbatus: The $L_{50}(10.4 \mathrm{~cm})$ for this species obtained with the $20-\mathrm{mm}$ sorting grid was close to the MLS $(11 \mathrm{~cm})$ of this species (Table 3$)$. No data were obtained with the square mesh codend because red mullet is a target species of demersal trawl fishery only in late summer and autumn.

Scomber scombrus: With the 20 -mm grid, the $L_{50}$ of $14.3 \mathrm{~cm}$ for $S$. scombrus was $4 \mathrm{~cm}$ below the
MLS (Table 3), suggesting that a substantially larger grid spacing would be needed to achieve adequate selectivity for this species.

Citharus linguatula and Triglidae: These are commercially exploited species but have no minimum landing size. The $L_{50}$ of $C$. linguatula was 9.3 $\mathrm{cm}$ with the 36-mm square mesh codend. With both sorting grids the $L_{50}$ was similar $(9.8-10.6 \mathrm{~cm}$; Table 3). The $L_{50}$ of Triglidae were 9.8 and $12.6 \mathrm{~cm}$ with the $20-\mathrm{mm}$ sorting grid and the $36-\mathrm{mm}$ square mesh codend respectively. The square mesh codend showed a narrower selection range than the $20-\mathrm{mm}$ grid (Table 3).

\section{DISCUSSION}

Iberian Mediterranean bottom trawl fisheries have shown an excessive increase in the fishing effort that has led to overexploitation of resources. The use of commercial small mesh size $(40 \mathrm{~mm}$ knotted polyamide -PA-) codends has led the yield 
per recruit to diminish with time as immature, firstage classes individuals are caught (Caddy, 1993). New sorting techniques other than diamond-shaped mesh codends, such as square mesh and sorting grids, are required to reduce catches of not-targeted fish, which can reach up to $34 \%$ of the total catch in weight in the Mediterranean (Sánchez et al., 2004). Our trials show that the $36-\mathrm{mm}$ square mesh codend and the $20-\mathrm{mm}$ sorting grid are both useful in reducing the catch of undersized hake and horse mackerel in the NW Mediterranean multispecies trawl fishery ( $L_{50}$ close to the MLS). Our $L_{50}$ estimated for hake with the $20-\mathrm{mm}$ sorting grid (ca $13.3 \mathrm{~cm}$ ) is close to that $(14.2 \mathrm{~cm})$ estimated earlier by Sardà et al. (2005) with a similar 20-mm grid. However, our estimates of selection range $(3.1$ and $2.4 \mathrm{~cm})$ are substantially smaller than theirs $(7.3 \mathrm{~cm})$, suggesting that small changes in rigging of the grid may cause major changes in $S R$. Our selectivity parameters for hake with the 40-mm square mesh $\left(L_{50}=18.5\right.$ $\mathrm{cm}, S R=5.1 \mathrm{~cm}$ ) were higher than those reported in the Balearic Islands $\left(L_{50}=15.4 \mathrm{~cm}, S R=4.5\right)$ (Guijarro and Massuti, 2006), probably due to the use in the islands of a thinner knotted PA netting operating in deepwater $(>500 \mathrm{~m})$ and at a lower speed ( 2.5 knots).

The $20-\mathrm{mm}$ sorting grid also came out as an effective selection device for red mullet. However, in case of smaller commercial species such as poor cod, the $36-\mathrm{mm}$ square mesh codend and the 20 -mm sorting grid would release large quantities of individuals that are above the MLS. Fishermen for whom this species is a significant target species would experience marked catch losses. Therefore, these devices are probably not acceptable for the fishing industry. On the other hand, for Atlantic mackerel the 20-mm spacing in a grid appears to be too small, so a trawl equipped with such a grid would retain large quantities of undersized mackerel.

It is also likely that seasonal changes in species distribution and recruitment as well as the different ability of various species to escape the devices may greatly affect the selection. The experiments were performed in two seasons, because the area is characterised by a relatively high abundance of hake in June and red mullet in September. Other very abundant species in the fishery such as the spottail mantis shrimp (Squilla mantis), the blue leg swimming crab (Liocarcinus depurator), the common octopus (Octopus vulgaris), and the red bandfish (Cepola macrophthalma) are not selected by sorting grid and square mesh, and they are not monitored because no MLSs are in force.

To optimise the overall selection performance in bottom-trawl fisheries in the Mediterranean, it may be necessary to use different selection techniques (e.g. mesh size/grid-spacing) for different seasons and for different fishing grounds. One solution will not work in all conditions.

This experiment highlights well the difficulty of improving size-selection in a multispecies fishery with a single selection technique. Clearly, the same mesh size or sorting grid spacing is not suitable for all species: it will be too large for some species and too small for others, and optimal selection could be achieved only for a few species. Requiring one mesh size (or grid spacing) to catch all these species all year round in various fishing grounds and fishing depths inevitably results in high discards and/or high catch-losses. Nevertheless, even if a precise optimum is not achieved for all species, a general increase in trawl selectivity in the Mediterranean Sea would increase the average age-at-capture for most commercial species, and would therefore improve the overall situation, increasing the long-term total yield from the fishery. It is noticeable that the use of squared mesh codends and sorting grids reduces discards and benefits the general community.

To attain marked improvements in this type of highly multispecies fishery, there should be a selectivity system in which the different type of species are first separated from each other, and then sorted by size (i.e. a multiple selection system). Effective improving of size-selection requires understanding season and depth variations of target and by-catch species, what makes difficult implementing a single mesh size or grid spacing in the Mediterranean demersal trawl fishery. Clearly, more focus should be given in the development of species selectivity to make the multispecies fishery in the Mediterranean sustainable.

\section{ACKNOWLEDGEMENTS}

The Direcció General de Pesca i Afers Marítims (DGPAM) of the Generalitat de Catalunya and CYCIT-MEC (PTR/1995-0497-OP) financially supported this study. The dedicated collaboration of the skipper and crew of the "Germans Felix" as well as the Confraria de Pescadors in Sant Carles de la Ràpita (Catalunya) is acknowledged. Artes de Pesca 
Salom S.L. (Benicarló, Spain) made the square mesh codends and grids. Constructive comments by Drs. J. Lleonart and N. Graham are appreciated. Special thanks are due to Dr. P. Suuronen for his valuable contribution.

\section{REFERENCES}

Caddy, J. - 1993. Some future perspectives for assessment and management of Mediterranean fisheries. Sci. Mar. 57: 121-130.

Guijarro, B. and E. Massuti. - 2006. Selectivity of diamond- and square-mesh codends in the deepwater crustacean trawl fishery off the Balearic Islands (western Mediterranean). ICES J. mar. Sci., 63: 52-67.

Larrañeta, M., P. Suau and J. San Felíu. - 1969. Experiencias de selectividad en la pesquería de arrastre en el Levante español. Inv. Pesq., 33: 15-53.

Lleonart, J. - 2001. Impact of fishery and environment on hake recruitment in Northwestern Mediterranean. EU FAIR CT-973522 (1998-2000), Barcelona.

Madsen, N. and K.E. Hansen. - 2001. Danish experiments with a grid system tested in the North Sea shrimp fishery. Fish. Res., 52: 203-216.

Martín, P., A. Carbonell and P. Belcari. - 2001. Estimation of trawl discards in the western Mediterranean. European hake (Merluccius merluccius) as case study. EC DG Fisheries Study 00/009. Final Report (mimeo): 135 pp.

Millar, B.R. and R.J. Fryer. - 1999. Estimating the size-selection curves of towed gears, traps, nets and hooks. Rev. Fish Biol. Fisher., 9: 89-116.

Millar, R. - 1992. Estimating the size-selectivity of fishing gear by conditioning on the total catch. J. Am. Statist. Assoc., 87: 962-968.
Polet, H. - 2002. Selectivity experiments with sorting grids in the North Sea brown shrimp (Crangon crangon) fishery. Fish. Res., 54: 217-233.

Sánchez, P., M. Demestre and P. Martín. - 2004. Characterisation of the discards generated by bottom trawling in the northwestern Mediterranean. Fish. Res., 67: 71-80.

Sardà, F., N. Bahamón, F. Sardà-Palomera and B. Molí. - 2005. Commercial testing of a sorting grid to reduce catches of juvenile hake (Merluccius merluccius) in the western Mediterranean demersal trawl fishery. Aquat. Living Resour., 18: 87-91.

Sardà, F., B. Molí and I. Palomera. - 2004. Preservation of juvenile hake (Merluccius merluccius, L.) in the western Mediterranean demersal trawl fishery by using sorting grids. Sci. Mar., 68: 435-444.

Stergiou, K., C.-Y. Politou, E. Christou and G. Petrakis. - 1997. Selectivity experiments in the NE Mediterranean: the effect of trawl mesh size on species diversity and discards. ICES J. mar. Sci., 54: 774-786.

Steward, P. - 2002. A review of studies of fishing gear selectivity in the Mediterranean. A review of studies of fishing gear selectivity in the Mediterranean. Report No. 9, (mimeo): 57 pp. Aberdeen, Scotland.

Tokai, T. - 1997. Maximum likelihood parameter estimates of a mesh selectivity logistic model through SOLVER on MSExcel. Bull. Jpn. Fish. Oceanogr., 61: 288-298.

Valdemarsen, J.W. and P. Suuronen. - 2003. Modifying fishing gear to achieve ecosystem objectives. In: M. Sinclair and G. Valdimarsson (eds), Responsible Fisheries in the Marine Ecosystem, pp 426. FAO and CABI International Publishing. Rome.

Wileman, D., R. Ferro, R. Fonteyne and R. Millar. - 1996. Manual of methods of measuring the selectivity of towed fishing gears. ICES Coop. Res. Rep. No. 215, pp 126. Copenhagen.

Scient. ed.: P. Abelló

Received January 13, 2006. Accepted February 24, 2006.

Published online June 30, 2006. 
